\title{
Türkiye İmalat Sanayiinde Enerji Tüketiminin İncelenmesi: Ayrıştırma Analizi
}

\author{
Alper YILMAZ* \\ Serap ÜRÜT KELLECI ${ }^{* *}$ \\ Aziz BOSTAN ${ }^{* * *}$
}

\section{Öz}

$\mathrm{Bu}$ çalışma Türkiye'de sanayi sektöründe tüketilen enerjinin değişimini ve bu değişimin nedenlerini ayrıştırma analizi yöntemi ile ortaya koymayı amaçlamaktadır. Sanayi sektörü, LDMI endeksine dayalı olarak, yıllık dönemler halinde ve alt sektörlere ayrılarak incelenmiştir. Analiz sonuçlarına göre imalat sanayi bütünü itibariyle çıktı etkisi kriz yılları hariç enerji tüketimini arttırıcı etki yapmıştır. Ayrıca enerji tüketimi üzerinde diğer iki etkiye göre daha belirleyicidir. Ekonomideki sektörel dönüşümlerin enerji tüketimi üstündeki etkisini gösteren yapısal etki ise imalat sanayi içinde enerji yoğun sektörlerin payının azalmasına bağlı olarak enerji tüketimini negatif etkilemiştir. Yoğunluk etkisi iki farklı eğilim göstermiştir. 1980 sonrasında dışa açılma dönemi ile birlikte sanayi sektörünün giderek daha fazla rekabet içine girmesi, ar-ge harcamalarının artması, dünyadaki yeni tekniklerin daha yakından takip edilmeye başlanması gibi nedenlerle enerji tüketimi üzerinde düşürücü etki yapmıştır. Ancak 2001 krizinden sonra kriz nedeniyle çıktıda meydana gelen hızlı düşme yoğunluk etkisini pozitife döndürerek enerji tüketimi üzerinde arttırıcı etki yapmasına neden olmuştur. Her üç etki değerlendirildiğinde sanayi sektöründe enerji yoğunluğunun yavaş bir düşme eğilimi içinde olduğu, daha az enerji yoğun sektörlere olan yapısal dönüşümün devam ettiği ve sanayi sektörü enerji tüketiminde çıktının hala baskın faktör olduğu görülmektedir.

Anahtar Kelimeler: Sanayi Sektörü, Enerji Tüketimi, Ayrıştırma Analizi

* Yrd. Doç. Dr., Adnan Menderes Üniversitesi, Söke İşletme Fakültesi, Uluslararası Ticaret ve İşletmecilik Bölümü

** Yrd. Doç. Dr., Aksaray Üniversitesi, İ̈BF, Maliye Bölümü

${ }^{* * *}$ Yrd. Doç. Dr., Adnan Menderes Üniversitesi, Nazilli İ̈BF, İktisat Bölümü 


\title{
Analysis of Energy Consumption in Turkish Manufacturing Industries: A Decomposition Analysis
}

\begin{abstract}
In this study, the change of the energy consumed in the industrial sector in Turkey and aims to reveal the cause of the decomposition analysis methods that change. The industrial sector, based on the LDM indices year period were examined and divided into subsectors case. According to the results of the analysis, the effect of output the manufacturing industry as a whole, except for the crisis years, had the effect of increasing the energy consumption. There are also more specific than the other two effects on energy consumption. Structural transformations in the economy that shows the impact on sectoral energy consumption if your domain is the decrease in the share of energy intensive sectors in the manufacturing industry, depending onthe energy consumption has had a negative impact. Density effect showed two different tendencies. Gradually the industry with the opening period to the outside after 1980 to enter into more competition, increased R\&D spending in the world to begin to follow more closely the new technique has the effect of reducing the energy consumption of such reasons. However, after the 2001 crisis, the impact caused rapid fall in output density occurring due to the crisis by turning to making a positive impact on energy consumption increase. When all three impact assessment industrial sector in energy density which is in a slow downward trend, less energy is continuing structural transformation with intensive sector and the industry seems to be still the dominant factor output in energy consumption.

Keywords: The Industrial Sector, Energy Consumption, Decomposition Analysis
\end{abstract}

\section{Giriş}

Enerji, bir maddenin ya da makinenin iş yapabilme yeteneğidir. Eski Yunan dilindeki $\varepsilon v(e n)=$ aktif ve $\varepsilon \rho \gamma o v i ́($ ergon $)=i s ̧$ kelimelerinden türemiş daha sonraları iş yapma yeteneği anlamında kullanılmaya başlanmıştır (Karluk, 1999: 247). Türk Dil Kurumu sözlüğünde ise enerji maddede var olan ve 1Sı, 1şık biçiminde ortaya çıkan güç olarak tanımlanmıştır (TDK, 1994: 603).

Enerji geçmişten günümüze insanoğlunun hayatının her alanında etkisini göstermektedir. Uygun koşullarda, yeterli miktar ve kalitede yararlanıldığı sürece, insanoğlunun medeniyet yolundaki ilerleyişinde 
hızlandırıcı olmuş, sosyo ekonomik hayatını olumlu etkilemiştir. Hayatını sürdürebilmesi için insanoğluna yaşam imkânı (hayat enerjisi) tanımıştır. Günümüzde ise modern hayatın vazgeçilmez bir parçası olmuş ve sanayiden, ulaşıma, teknolojik gelişmelerden sosyal hayata insan hayatının kilit taşlarından biri konumuna gelmiştir. Artık modern hayatımızda enerji olmazsa olmaz bir koşuldur (Fay and Glomb, 2002). Özellikle Türkiye gibi gelişmekte olan ülkelerde enerji ile ekonomik ve sosyal gelişme arasındaki bağ daha kuvvetlidir. Bu ülkelerin enerjiye olan bağımlılığı daha fazladır. Yapılan hesaplamalara göre bu ilişkideki esneklik katsayısı 1'e yakın çıkmaktadır. Esneklik katsayısının 1 olması, ekonomide yüzde 1'lik büyüme durumunda genel enerji talebinin de yüzde 1 oranında artması demektir. Gelişmiş ülkelerde ise enerji ve ekonomik büyüme arasındaki bağ zayıfladığı için bu sayı sıfıra doğru yaklaşır. Bu aynı zamanda birincil enerji yoğunluğunun da düştüğü anlamına gelir (Saatcioğlu ve Küçükaksoy, 2004: 1-2).

\section{Türkiye'de Sanayi Sektöründe Enerji Tüketimi}

Geçmişten günümüze enerjinin öneminin artmasında nüfus artışının, şehirleşme oranının artmasının, beklentilerin ve yaşam standartlarının yükselmesinin ve sanayi devriminin yarattığı yeni üretim anlayışının etkili olduğu söylenebilir. Özellikle sanayi devrimiyle birlikte buhar gücüyle çalışan makineler, makineleşmiş endüstriyi doğurmuş ve enerji tüketiminde önemli artışlara neden olmuştur. Sanayileşmenin makineleşmesi demek, üretimin kas gücünden çıkıp, daha çok makinelere dayanması, yani enerjiye dayanması ve dolayısıyla enerji talebinin hızla artması demektir (Tandoğan, 1994: 13-16).

Osmanlı Devleti ve Türkiye Cumhuriyetinin ilk yılları için sanayi sektörü enerji tüketimi zayıftır ve hizmetler sektörünün gerisinde kalmıştır. Bunun en büyük nedeni sanayi sektörünün cılız gelişimi, teknolojik gerilik, emek yoğun üretim tekniklerinin yaygınlığı ve ticari olmayan enerji kaynaklarının yaygın kullanımıdır. Ancak yeni kurulan Türkiye Cumhuriyeti tam bağımsızlık için, ekonomik büyüme ve kalkınma için sanayi sektörüne büyük önem vermiştir. Modern üretim tekniklerinden uzak, tarım sektörünün ağırlıklı olduğu bir ekonomik yapıda, yapılan uzun vadeli kalkınma planlarıyla, ekonomide sanayi sektörünün ağırlığının artacağ1 bir yapısal dönüşüm hedeflenmiştir. İşte bu dönüşüm enerji tüketiminde önemli değişikler meydana getirmiştir. Süreç içinde sanayi sektöründe enerji tüketimi payını arttırırken hizmetler sektörünün toplam enerji tüketimi içindeki payı azalmış, tarım sektörünün payı ise sınırlı kalmaya devam etmiştir (DTM, 2006: 1). Türkiye ekonomisi genel enerji 
tüketimi de ekonomik ve sosyal gelişmelerle paralel olarak yıldan yıla artmıştır.

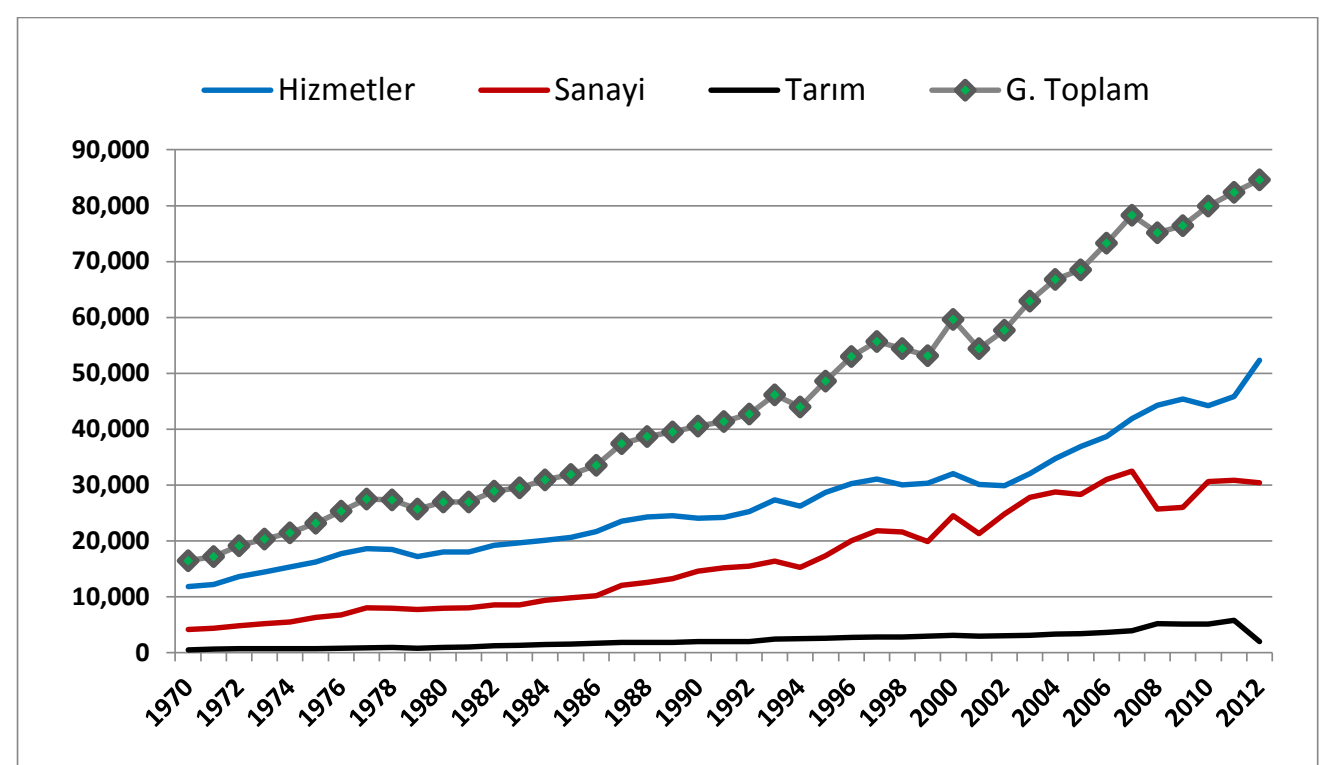

Şekil 1. Türkiye Ekonomisinde Sektörel Enerji Tüketimi (Btep)

Kaynak: Enerji Bakanlığı Genel Enerji Dengesi Tabloları, 1970-2012

Şekil 1'de görüldüğü gibi 1970 yılında 16.4 Mtep olan sektörel tüketim, ortalama \%4.29 artışla 2012 yılında 84.6 Mtep'e çıkarken, tarım sektörünün payı $\% 3^{\prime}$ ten $\% 6^{\prime}$ ya çımış, Hizmetler sektörünün payı $\% 72$ 'den $\% 55$ 'e gerilemiş ve sanayi sektörünün payı $\% 25^{\prime}$ ten $\% 32$ ye çıkmıştır. 


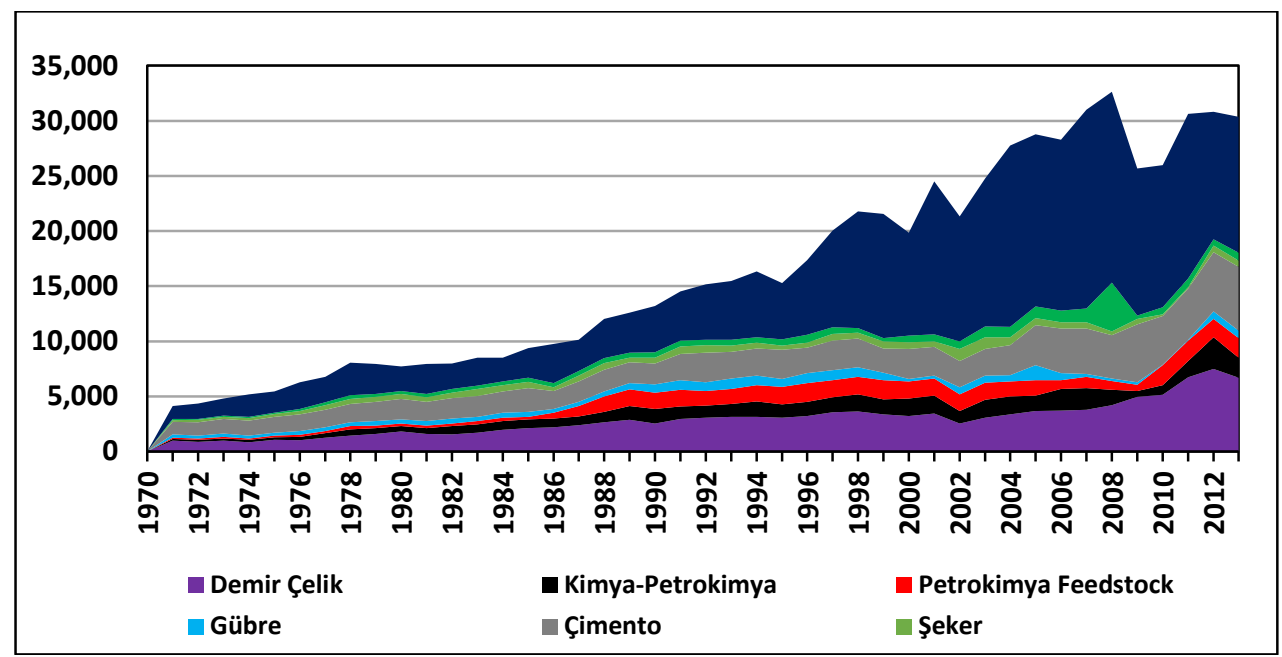

Şekil 2. İmalat Sanayi Alt Birimleri İtibariyle Enerji Tüketimi (Btep)

Kaynak: Enerji Bakanlığı Genel Enerji Dengesi Tabloları, 1970-2012

Şekil 2'de ise 1970-2012 arasında sanayinin alt sektörleri itibariyle enerji tüketimi verilmektedir. Genel olarak bakıldığında imalat sanayi enerji tüketimi 1970 yılında 4.122 Btep'ten yıllık ortalama \%4.2 artışla 2012 yılında 30.369 Btep'e çıkmıştır. Ancak bu artış temposu azalan eğilimlidir. Örneğin 1970-1980 arası büyüme hızı \%6.56, 1980-1990 arası \%5.14, 1990-2000 arası \%3.74 ve 2000-2012 arası \%2.51'dir. Artış hızının azalması sanayi sektöründe enerji yoğunluğunun azalmasının bir göstergesidir.

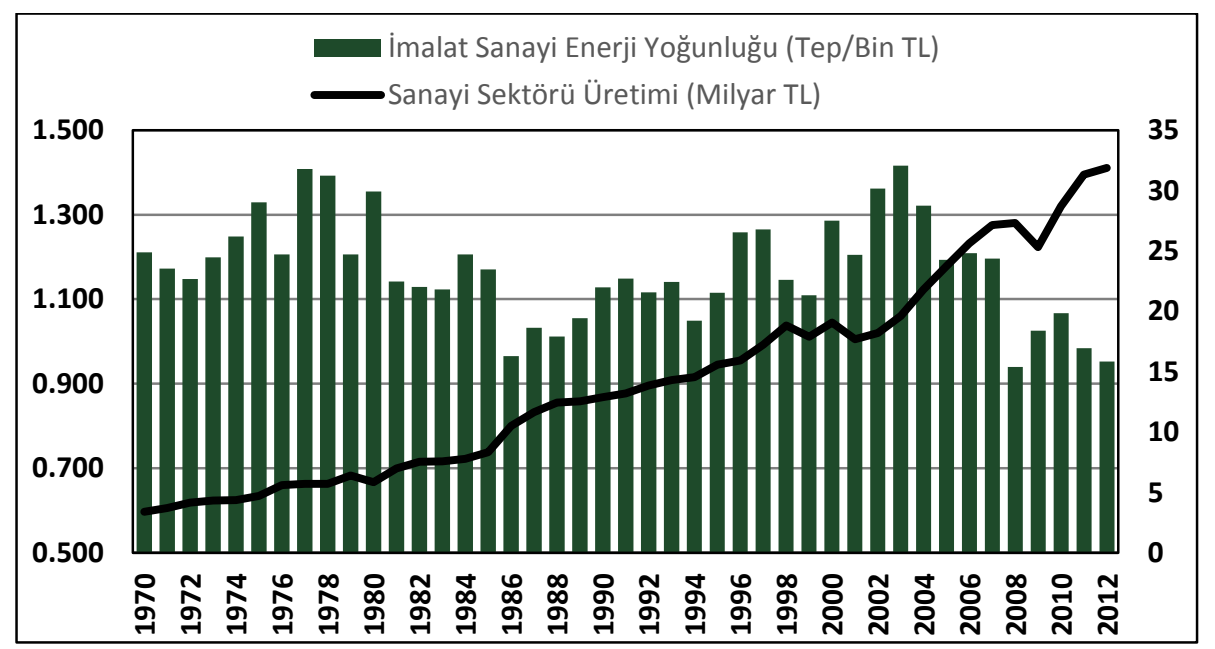

Şekil 3. Sanayi Sektöründe Enerji Yoğunluğu

Kaynak: Enerji Bakanlığı Genel Enerji Dengesi Tabloları, 1970-2012 
Şekil 3'te sağ eksende sanayi sektöründe 1998 fiyatlarıyla yaratılan GSYH, sol eksende ise Tep/Bin TL cinsinden 1000 TL'lik çıktı için ne kadarlık enerji tüketildiğini göstermektedir. Şekilde görüldüğü gibi sanayi sektöründe enerji yoğunluğu her ne kadar dalgalı seyir izlese de 1970-2012 arası yıllık ortalama \%0.18 düşüle 1.211 bin TL/Tep'den 0.935 Tep/Bin TL'ye gerilemiştir. 1970-1980 arası korumacı iktisat politikalarının uygulandığı ve enerji fiyatlarının düşük seyrettiği dönemde enerji yoğunluğu ortalama \%2 artış gösterirken, 1980 sonrası dışa açılma politikalarıyla birlikte tekrar düşüş trendine girmiş ancak 1986-2003 arasında ortalama \%2.53 artışla 1.416 'ya çıkmıştır. Yoğunluk etkisi esas düşme eğilimini 2004 yılından sonra göstermiş ve ortalama \%4 düşüşle 0.953 Tep/Bin TL'ye inerek tüm dönemdeki en düşük değerine gerilemiştir.

Şekil 4'te ise sanayi alt dalları içinde enerji tüketimi ile öne çıkan yani enerji yoğun sanayi dallarının sanayi sektörü enerji tüketimi içindeki değerleri verilmiştir. 2012 yılı itibariyle çimento (5770 Btep), demir-çelik (6750 Btep), kimya-petrokimya (1806 Btep) ve tekstil (1935 Btep) endüstrileri imalat sanayi içinde öne çıan sektörlerdir. Söz konusu sektörler 1970 yılından günümüze paylarını azaltarak faaliyet göstermektedirler.

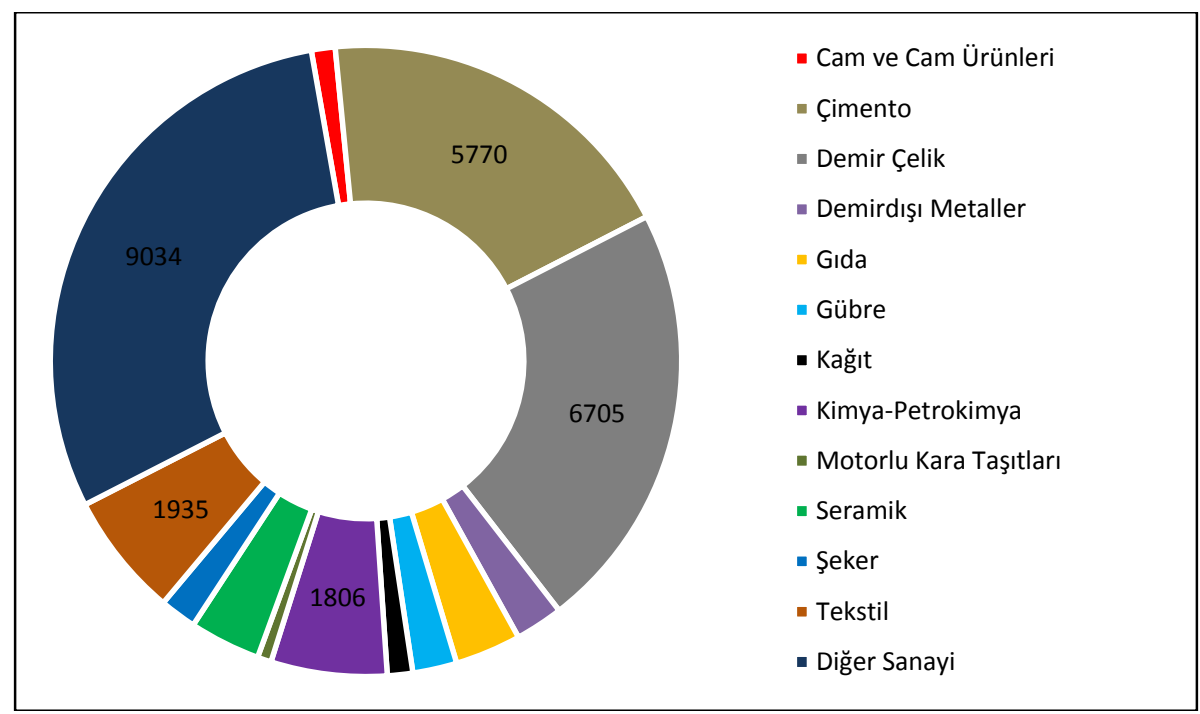

Şekil 4. İmalat Sanayi Alt Birimleri Enerji Tüketimi (2012, Btep)

Sanayi sektöründe enerji tüketiminin artması etkileyen iki önemli etken vardır. İlki gelir seviyesidir. Ülkelerin gelir seviyesi arttıkça tüketim harcamaları kanalıyla toplam talep artacak, artan toplam talebi karşılamak 
isteyen firmalar üretimlerini arttıracaklardır. Üretim artışı ise enerji tüketimindeki artışı beraberinde getirecektir. Ancak bir noktadan sonra aralarındaki bu ilişki zayıflamaya başlar ve yüksek gelir seviyesindeki ülkeler için gelirin, enerji tüketimlerindeki değişimi açıklama gücü azalır. Yani aralarında ters $\mathrm{u}$ şeklinde bir ilişki vardır. Artık zenginleşen ülkede daha verimli enerji kaynaklarının tüketimdeki payı artmaya başlar, enerji sistemleri daha verimli hale getirilir. Enerji yoğunluğunun azaldığını gösteren bu duruma göre gelirin açıklama gücü, düşük ve orta gelirli ülkelerde daha yüksektir (Foster vd., 2000: 2-3). Bunun en önemli nedenlerinden biri, yapısal değişim sonucunda yüksek katma değerli daha az enerji yoğun sektörlerin gelişmiş ekonomilerde ekonomi içindeki payının artması ve hizmetler sektöründeki hızlı büyümedir. Gelişmiş ülkeler özellikle 1979 petrol krizi sonrasında enerji yoğun endüstrilerden uzaklaşmaya başlamışlardır.

İkincisi nihai taleptir. Özellikle sanayi ürünlerine artan talep, beraberinde enerji tüketimindeki artışı da getirmiştir, çünkü talep arttıkça üretim de artacak, üretim arttıkça da enerji tüketimi artacaktır. Bu noktada GSYİH ve enerji tüketimi arasındaki nedensellik ilişkisini inceleyen pek çok çalışma yapılmıştır. Bu çalışmalarda enerji tüketimi ve ekonomik büyüme arasında pozitif yönlü nedensellik ilişkisi bulunmuştur. Yani ülkelerin ekonomik büyüme hedefleri, o ülkenin belli bir seviyede enerji tüketmesini gerektirmektedir. Ülkenin ekonomik büyüme oranının artması, enerji tüketimini arttırmaktadır (Orhan, 2007: 1-2). Kraft ve Kraft (1978) tarafından ABD'nin 1947-1974 dönemini içeren ve Sims'in nedensellik analizi kullanılarak yapılan çalışmada, enerji tüketimi ve GSMH arasındaki ilişki incelenmiş ve GSMH'dan enerji tüketimine doğru tek yönlü bir nedensellik ilişkisi bulmuşlardır (Kraft and Kraft, 1978: 401-403).

Türkiye için yapılan çalışmalarda da enerji tüketiminden milli gelire doğru bir nedensellik ilişkisinin varlığı tespit edilmiştir, dolayısıyla enerji kullanımındaki değişiklikler, enerji yoğunluklarındaki değişmeler, sektörel enerji kullanımı ve uygulanacak enerji politikaları ekonomik büyümeyi doğrudan etkileyecektir. Bu noktada sanayi sektörü enerji tüketiminde önemli paya sahip olduğu için enerji kullanımındaki değişikliklerden en fazla etkilenecek sektörlerin başında gelecektir. Sanayi sektöründe enerji kullanımındaki değişiklikler ve enerji tüketim yapısı hem genel enerji tüketimini hem da ekonomik büyümeyi etkileyecektir. Sanayi sektörü alt kategorilerinde, daha önce belirtilen sektörlerin enerji kullanımlarındaki payları da farklı olduğu için alt sektörlerin etkilenme derecesi de farklı olacaktır. Bazı sektörlerin enerji tüketimleri daha fazla olduğu için, çıktı, yoğunluk ve yapısal etki üzerindeki etkisi daha fazla olacaktır. 


\section{Literatür Taraması}

Literatürde ayrıştırma analizi yöntemiyle enerji göstergelerindeki değişimin hangi nedenlerden kaynaklandığ 1 ve bu değişimin etkilerinin neler olduğuna dair pek çok çalışma mevcuttur. Ma ve Stern (2007) 19802003 yılları arası Çin ekonomisinde enerji yoğunluğundaki değişimi LMDI yöntemiyle incelemiş, analiz sonuçlarına göre teknolojik ilerlemenin enerji yoğunluğundaki düşüşün en önemli nedeni olduğunu ortaya koymuşlardır. Bazı sektörlerdeki yoğunluk artışını ise negatif teknolojik ilerleme ile açıklamışlardır. Endüstriyel ve alt endüstriyel düzeyde meydana gelen yapısal değişimler ise enerji yoğunluğunu arttırıcı etki yapmıştır.

Cornillie ve Frankhauser (2004) çalışmasında 1992-1998 döneminde Orta ve Doğu Avrupa ve eski Sovyet bloku ülkeleri için enerji yoğunluklarını incelemiştir. Analiz sonuçlarına göre Ilk grup ülkelerde (Macaristan, Slovenya, Litvanya gibi) milli gelir içinde ağır sanayinin ağırlığının devam etmesi ve bu sektörlerde teknolojinin hızlı yenilenememesi enerji yoğunluğunun düşmesini engellemektedir. Üçüncü gruptaki ülkelerde ise sanayi sektöründe yeniden yapılandırmanın gecikmesi nedeniyle enerji yoğunluğu düşeceği yerde artmıştır.

Greening ve diğerleri (1997) 1970-1992 dönemi 10 OECD ülkesi için enerji yoğunluğunu altı farklı ayrıştırma yöntemiyle incelemiştir. Ampirik bulgulara göre ülkelerin genel enerji yoğunluğu imalat sanayinde enerji yoğun sektörlerin ne derece pay sahibi olduğuna bağlıdır. Bu tip sektörlerin payının artması yapısal etkiyi arttırmakta ve enerji tüketimindeki artışa pozitif katkı yapmaktadır.

Steenhof (2006) Çin sanayisi elektrik talebini 1998-2002 yılları arasında Las-Peyers yöntemiyle incelemiştir. Çalışmada sanayi sektörünü birincil sektörler $(\mathrm{P})$, ikincil sektörler (S-P) ve ikincil imalat sanayi (S-M) olarak üç kısma ayırılmıştır. Sonuçlara göre elektrik tüketimi 1998-2002 yılları arasında çıktı etkisi nedeniyle 579 Twh artmıştır. Fakat talepte meydana gelen 242 Twh'lik azalma enerji yoğunluklarındaki değişime ve yapısal değişime atfedilebilir. Yani hızlı sanayileşmenin elektrik talebinde meydana getirdiği arttırıcı etki verimlilik artışları ve yapısal etki tarafından dengelenmiştir. Üretimdeki artış beraberinde enerji talebinde artışı getirmiştir. Fakat ağır sanayi dallarında enerji verimliliğinde görülen iyileşme alt sektörel düzeyde enerji yoğunluğunu düşürmüştür. Elektrik talebinin artmasındaki en önemli nedenlerden biri yakıt tipinde meydana gelen değişikliklerdir. 


\section{Metod}

Çalışmada sanayi sektörü enerji tüketimi ayrıştırma analizi yöntemiyle incelenmiştir. Ayrıştırma analizi endeks sayılar problemine dayalıdır. Fakat daha çok enerji tüketimi, enerji verimliliği ve sera gazı emisyonları gibi değişkenlerde meydana gelen değişikliklerin analizi için kullanılmaktadır. Özellikle ekonomik büyümenin, üretim faktörlerinin sektörler arası değişiminin ve teknolojik değişimin çevresel ve sosyoekonomik göstergeler üzerindeki etkisinin belirlenmesinde oldukça faydalıdır (Granel, 2003: 6-8).

Ayrıştırma analizine göre, değişime uğrayan bir faktörün temel yıldaki (genellikle $\mathrm{T}_{0}$ olarak sembolize edilir) değeri ile daha sonraki yıl veya yıllardaki değeri (genellikle $\mathrm{T}_{1} \ldots . . \mathrm{n}$ olarak sembolize edilir) karşılaştırılır ve aradaki üretim, yoğunluk ve yapısal etki bakımından bakımından incelenerek yorumlanır (Stenhof, 2006: 377).

Literaturde çok çeşitli analiz yöntemleri vardır. Bu çalışmada toplamsal tipteki LMDI (Linear Mean Divisia Index) yöntemi seçilmiştir. Ang ve Liu (2001), Ang (2004), Ang vd. (1998) yaptıkları çalışmalarda daha küçük artık değer vermesi, içinde sıfır değerine sahip olan serileri de işleyebilmesi, toplamsal tutarlılık, kolay uygulanabilmesi ve yorumlanabilmesi nedeniyle LMDI yönteminin diğer yöntemlere tercih edilebileceğini belirtmişlerdir. Model şöyledir;

$$
\Delta \mathrm{E}_{\text {tot }}=\Delta \mathrm{E}_{\mathrm{prd}}+\Delta \mathrm{E}_{\text {str }}+\Delta \mathrm{E}_{\text {int }}+\Delta \mathrm{E}_{\mathrm{rsd}}(1)
$$

Buna göre 0 yılından $t$ yılına enerji tüketimindeki toplam değişim (Etot), çıktı etkisi (Eprd), yapısal etki (Estr), yoğunluk etkisi (Eint) ve artık değer (Ersd) şeklinde dört kısma ayrılabilir. Üretim etkisi, enerji tüketiminde üretim miktarındaki artıştan kaynaklanan etkiyi gösterir. Üretimin artması enerji tüketiminin de artması anlamına gelir ve çıktı etkisi enerji tüketimini pozitif yönde etkiler (Zhang, 2003: 625-638). Yoğunluk etkisi, sosyo ekonomik gelişmelerin, teknolojik değişimin, teknolojik yeniliklerin ve üretim sistemlerindeki değişikliğin enerji tüketimi üzerindeki etkisidir. Eğer çıktıdaki artış oranı, enerji girdisindeki artış oranından büyükse yoğunluk etkisi azalmaktadır. Daha etkin, verimli üretim tekniklerinin uygulanması, etkin enerji yönetimi, o alt sektörün içinde veya alt sektörler arasında ürün karmasında meydana gelen değişmeler, malzemeve yakıt girdisinin kalitesinde meydana gelen iyileşmeler yoğunluk etkisini azaltır. Teknolojik değişim hızlandıkça yoğunluk etkisi daha hızlı düşer. Negatif teknolojik ilerleme ise enerji yoğunluğunu arttırır. Enerji üretiminde kapasite kullanım 
oranının artması yoğunluk etkisini arttırır. Üretim faktörlerinin sektörler arası değişimine neden olan yapısal değişimde de yoğunluk etkisini etkiler. Diğer yandan ülkelerin sanayileşme oranlarının artması, elektrikli alet ve edevatın daha çok kullanılması, elektrikli ev aletlerinin yaygınlaşması yoğunluk etkisini artırıcı etki yapar. Bu yüzden gelişmekte olan ülkelerde enerji yoğunluğu, gelişmiş ülkelere göre daha fazladır (Steenhof, 2006: 370384).

Bu noktada enerji yoğunluğu ne kadar düşerse, belli bir miktar çıtı üretmek için o kadar az enerji kullanılıyor demektir. Bu aynı zamanda enerjinin de o kadar verimli kullanıldığı anşlamına gelir. Yani enerji verimliliği ile enerji yoğunluğu arasında ters ilişki vardır. Olması istenen de budur. Artık belli miktar çıktı için enerjiye o kadar az para harcanıyor demektir. Ülkeler geliştikçe enerji yoğunluğunun düşmesi, enerji verimliliğinin artması beklenir. Zaten gelişmiş ülkelere bakıldığında söz knousu göstergelerin gelişmekte olan ülkelerden daha iyi olduğu, bu göstergelerin belli bir seviyede olduğu görülür (Narin, 2006: 61)

Yapısal etki toplam üretimin sektörel payı içindeki değişimin, enerji tüketimi üzerindeki etkisini ortaya koyar. Toplam üretim içinde enerji yoğun sektörlerin payının artması yapısal etkiyi arttırır. Böyle bir değişme toplam enerji talebi üzerinde arttırıcı etki yapar ve enerji tüketimindeki büyüme oranı artar. Eğer daha az enerji yoğun sektörlerin payı artarsa bu sefer toplam enerji talebi üzerinde düşürücü etki yapacak ve enerji tüketimindeki büyüme oranı azalacaktır (Vehmas, 06.05.2010: upav.org.tr). Burada da ekonomi içinde daha az enerji yoğun olan sektörlerin payının artması, enerji yoğun sektörlerin payının azalması istenir. Böylelikle enerji talep artış baskısı hafifleyecek, enerji verimliliği artacak, enerji yoğunluğu düşecek, enerji kaynaklı çevresel kirlenmeler azalacaktır. Her bir sektörde çıktı, yapısal ve yoğunluk etkilerini hesaplamak için şu formüller kullanılır;

$$
\begin{aligned}
\Delta E_{a c t} & =\sum_{i}^{n} \frac{E_{i, j}^{t}-E_{i, j}^{0}}{\ln E_{i, j}^{t}-\ln E_{i, j}^{0}} \ln \left(\frac{Q^{t}}{Q^{0}}\right) \\
\Delta E_{s t r} & =\sum_{i}^{n} \frac{E_{i, j}^{t}-E_{i, j}^{0}}{\ln E_{i, j}^{t}-\ln E_{i, j}^{0}} \ln \left(\frac{S_{i, j}^{t}}{S_{i, j}^{0}}\right) \\
\Delta E_{\mathrm{int}} & =\sum_{i}^{n} \frac{E_{i, j}^{t}-E_{i, j}^{0}}{\ln E_{i, j}^{t}-\ln E_{i, j}^{0}} \ln \left(\frac{I_{i, j}^{t}}{I_{i, j}^{0}}\right)
\end{aligned}
$$


Burada $E_{i}$ ton eşedeğer petrol (tep) cinsinden i sektörü için birincil enerji tüketimini, $Q^{0}$ ve $Q^{t}$, i sektöründeki 0 ve $t$ yıllarındaki toplam üretimini, $S_{i}^{t}$ and $S_{i}^{0}$, i sektörünün 0 ve t yıllarında toplam üretim içindeki paylarını, $I_{i}^{t}$ and $I_{i}^{0}$, i sektörünün 0 ve t yıllarındaki enerji yoğunluklarını tep/Bin TL cinsinden verir. Son olarak i sektörünün de altındaki alt sektörleri j sektörü temsil etmektedir. Küçük $n$ ise imalat sanayinin altındaki alt sektörlerin (demir-çelik, gübre, şeker, kimya-petrokimya, rafineri, demirdışı metaller, çimento ve diğer sanayi dalları) sayısını gösterir.

\section{Veri}

Veriler TUiK ve enerji bakanlığı verilerinden toplanmıştır. Enerji verileri ve reel gelir sırasıyla bin ton eşdeğer petrol (Btep) ve TL cinsinden verilmiştir. Reel geliri temsilen her bir alt sektörde yaratılan nominal katma değerler reel değerlere çevrilerek kullanılmıştır. Sektörel katma değerler ISIC Rev.2 4 haneli ayrıma göre sınıflandırılmış tablolardan alınmıştır. Sektörlerin üretim içindeki payları yüzde cinsinden gösterilirken, enerji yoğunlukları tep/Bin TL cinsinden yani çıktı başı tüktilen enerji miktarını vermektedir. Sanayi kesimi, kimya-petrokimya, petrokimyasal hammadde, gıda, çimento, gübre, demir-çelik, şeker, demir dışı metaller, kağıt, cam ürünleri, motorlu kara taşıtları, tekstil ve diğer sanayi şeklinde alt kısımlara ayrılmıştır. Birincil enerji tüketimi içinde, çevrim sektörü ve enerji dışı alanlar için kullanılan tüketim hariç tutulmuştur.

\section{Ampirik Sonuçlar}

Sanayi alt sektörlerine ait reel katma değerler ve kullanılan enerji değerleri 2, 3 ve 4 nolu eşitlikler kullanılarak analiz edildiğinde tablo 1'deki sonuçlar elde edilir. Sanayi sektörü enerji tüketimi 1980 yllında 7.955 Btep'ten 22.875 Btep artışla 2011 yılında 30.628 Btep'e çıkmıştır. Bu artış yıllar itibariyle ayrı̧̧tırma analizine göre çıktı, yapısal ve yoğunluk etkisi olarak ayrıştırıldığında Tablo 1'deki sonuçlar elde edilir. Örneğin sanayi sektörü enerji tüketimi 1980 yılında 7.955 Btep'ten 1981 yılında 32.3 Btep artarak 7.987 Btep'e çıkmıştır. Bu artışta çıktı etkisi 1634.3 Mtep'lik pozitif katkı sağlarken yoğunluk etkisi 902.1 Mtep ile negatif, benzer şekilde yapısal etki 700 Btep negatif değer alarak söz konusu yılda enerji tüketimini düşürücü etkide bulunmuştur. Her üç etkiyi topladı̆̆ımızda sanayi sektöründe o yılki gerçekleşen enerji tüketim artışına eşit olmaktadır. 
A. YILMAZ, S. ÜRÜT KELLECİ, A. BOSTAN | 216

Tablo 1. İmalat Sanayi Enerji Tüketimi Ayrıştırma Analizi Sonuçları (Btep)

\begin{tabular}{|c|c|c|c|c|c|c|c|c|c|}
\hline Yıllar & $\begin{array}{c}\text { Çıtı } \\
\text { Etkisi }\end{array}$ & $\begin{array}{c}\text { Yapısal } \\
\text { Etki }\end{array}$ & $\begin{array}{c}\text { Yoğunluk } \\
\text { Etkisi }\end{array}$ & $\begin{array}{c}\text { Enerji } \\
\text { Tüketiminde } \\
\text { ki Değişim }\end{array}$ & Yıllar & $\begin{array}{c}\text { Çıtı } \\
\text { Etkisi }\end{array}$ & $\begin{array}{c}\text { Yapısal } \\
\text { Etki }\end{array}$ & $\begin{array}{c}\text { Yoğunluk } \\
\text { Etkisi }\end{array}$ & $\begin{array}{c}\text { Enerji } \\
\text { Tüketiminde } \\
\text { ki Değişim }\end{array}$ \\
\hline 1981 & 1634.3 & -700.0 & -902.1 & 32.3 & & & & & \\
\hline 1982 & 673.4 & -503.7 & 357.1 & 526.9 & 1997 & 3837.9 & 1125.8 & -3224.1 & 1739.6 \\
\hline 1983 & 265.4 & -448.2 & 188.2 & 5.4 & 1998 & 82.6 & -1690.5 & 1372.7 & -235.2 \\
\hline 1984 & -300.4 & -35.1 & 1205.0 & 869.4 & 1999 & 1013.8 & 102.6 & -2797.7 & -1681.3 \\
\hline 1985 & 1249.1 & 355.3 & -1213.8 & 390.5 & 2000 & -768.3 & 903.8 & 4492.5 & 4628.1 \\
\hline 1986 & 3147.6 & -703.4 & -2077.9 & 366.3 & 2001 & 2005.7 & -1256.0 & -3926.9 & -3177.2 \\
\hline 1987 & 249.9 & 941.9 & 700.6 & 1892.4 & 2002 & -6604.7 & 216.4 & 9846.3 & 3458.0 \\
\hline 1988 & 2097.2 & -165.3 & -1387.1 & 544.7 & 2003 & 1067.4 & -1471.8 & 3399.4 & 2995.0 \\
\hline 1989 & 291.4 & 27.4 & 317.5 & 636.3 & 2004 & 1404.0 & 2633.1 & -3025.0 & 1012.1 \\
\hline 1990 & 1716.3 & -940.5 & 547.7 & 1323.6 & 2005 & -4718.8 & 866.1 & 3345.0 & -507.8 \\
\hline 1991 & 1836.7 & 257.0 & -1455.6 & 638.2 & 2006 & 3773.4 & 1287.9 & -2346.9 & 2714.4 \\
\hline 1992 & 1612.3 & 390.5 & -1729.2 & 273.6 & 2007 & -464.5 & -552.1 & 2664.6 & 1648.0 \\
\hline 1993 & 2545.9 & -241.4 & -1426.2 & 878.3 & 2008 & 1749.1 & 591.4 & -9307.5 & -6967.0 \\
\hline 1994 & -1255.8 & -238.6 & 433.5 & -1060.8 & 2009 & -2673.8 & -6766.0 & 9728.7 & 289.0 \\
\hline 1995 & 151.2 & -1290.6 & 3240.0 & 2100.5 & 2010 & 2149.9 & 4203.4 & -1691.3 & 4662.0 \\
\hline 1996 & -507.6 & -389.7 & 3575.4 & 2678.0 & 2011 & 4771.5 & 1181.9 & -5751.4 & 202.0 \\
\hline
\end{tabular}

Çıktı etkisi, toplam birincil enerji tüketiminde üretim miktarındaki artıştan kaynaklanan etkiyi gösterir. Artan ekonomik çıktı faaliyet etkisini artırır, enerji tüketimindeki büyüme oranını artıcı etki yapar. Enerji tüketimindeki artışa pozitif katkıda bulunur. Eğer çıktı düşerse, çıktı etkisi, enerji talebi artış oranını düşürür ve enerji tüketimindeki değişmeye negatif olarak etki eder (Zhang, 2003: 625-638). 


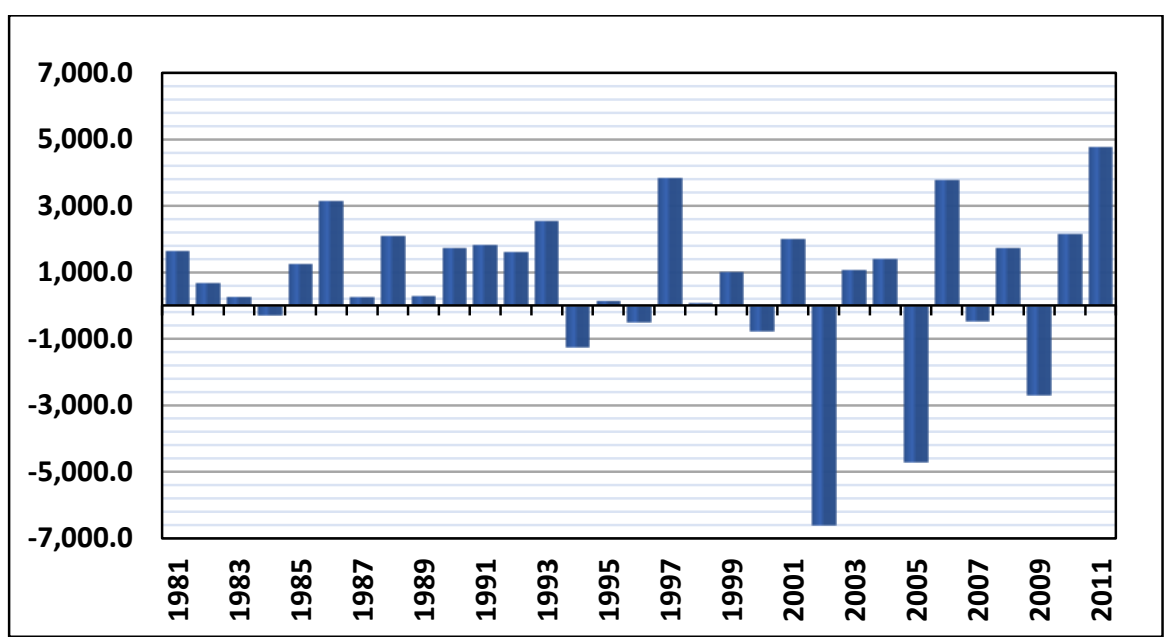

Şekil 5. Çıktı Etkisi (Btep)

Şekil 5'te görüldüğü gibi çıktı etkisi 1994, 2001 ve 2009 yıllarında ekonomik krizler nedeniyle, 1984, 1996, 2005 ve 2007 yıllarında yaratılan reel katma değerdeki daralma nedeniyle eksi değerler alarak enerji tüketimini düşürücü etki yapmış, diğer tüm yıllarda üretim artışı nedeniyle pozitif değerler almıştır. Tüm dönem itibariyle değerlendirildiğinde enerji tüketimini 22.032 Btep arttırmıştır. Çıktı etkisinde öne çıkan alt sektörler demir-çelik, çimento ve kimya-petrokimya ve rafineri sanayileridir. $\mathrm{Bu}$ sektörlerde enerji tüketimi diğer alt sanayi dallarına göre daha fazladır.

Yoğunluk etkisinde negatif alınan değerler ilgili yılda enerji yoğunluğunun düştüğünü, pozitif alınan değerler ise arttığını gösterir. Enerji yoğunluğunun düşmesi, artık aynı miktarda çıktı daha az enerji kullanılarak üretilmiş demek olduğu için toplam enerji tüketimindeki artış üzerinde düşürücü etkide olacaktır. 


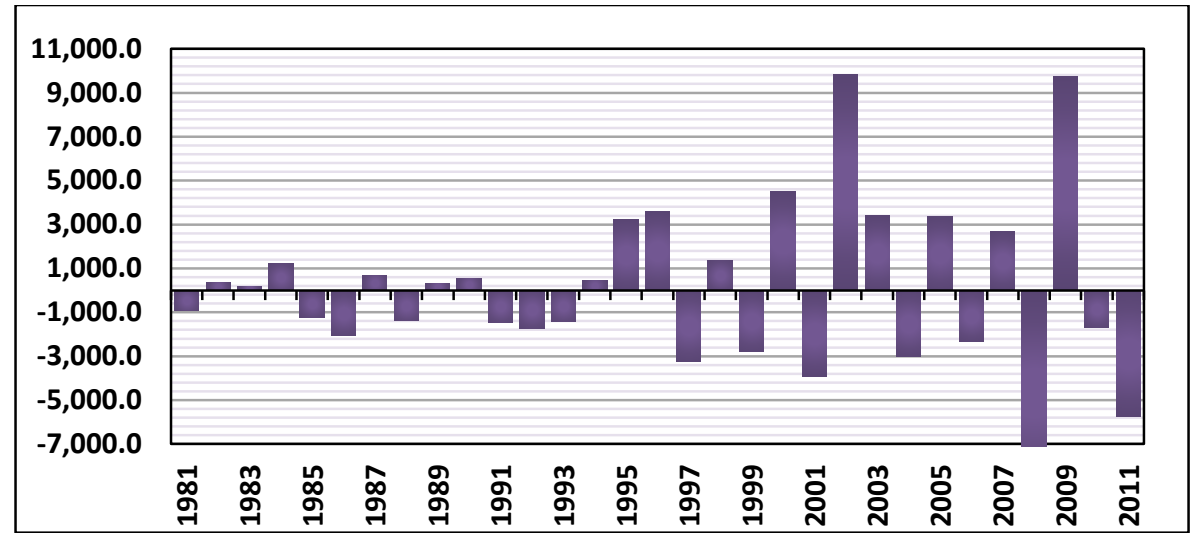

Şekil 6. Yoğunluk Etkisi (Btep)

Yoğunluk etkisi bazı yıllarda negatif, bazı yıllarda pozitif değerler almıştır. 1990öncesinde ekonominin büyüklüğü, sanayi kesimi enerji tüketimi, sanayi sektörünün kapasitesi, milli gelir düzeyi ve buna bağlı olarak değişen toplam talebin 1990 sonrasına nispeten daha az olması nedeniyle, 1980-1990 döneminde yoğunluk etkisi 1990-2009dönemine göre daha düşüktür. 1980 dönüşümü ile ihracata dayalı büyüme modelini benimseyen Türkiye'de, hızlı üretim artışı dolayısıyla sanayi kesimi enerji tüketimi, artan üretime paralel olarak artmaya başlamıştır. Ancak krizden çıkış dolayısıyla meydana gelen hızlı üretim artışı, enerji yoğunluğunda düşüş getirmiş ve yoğunluk etkisi, Kimya-Petrokimya ve Demir dişı metaller sektörlerindeki arttırıcı etki haricinde diğer sektörlerde düşerek 1981 yılında -902 Btep olmuştur. İlerleyen zamanda1985, 1986 ve 1988 yıllarında negatif, diğer yıllarda pozitif değerler almıştır. Ancak 1980-1990 döneminin tümü değerlendirildiğinde yoğunluk etkisi enerji tüketiminde 2812 Btep'lik bir tasarrufa neden olmuştur. Bu on yıllık dönemde Petrokimyasal hammadde, Şeker ve Kimya - Petrokimya sektörleri hariç diğer tüm sektörlerde yoğunluk etkisi azalmıştır. Kapasite kullanım oranının artması ve hızlı üretim artışına bağlı ekonomik büyüme beraberinde enerji tüketiminde hızlı bir artışa neden olmuştur. Yoğunluk etkisi aldığı negatif değerlerle bu dönemde etkin enerji kullanımı ve teknolojileri ile enerji tasarruf edici tekniklerden yeterince faydalanıldığını göstermiştir.

1990-2000 döneminde 1991, 1992, 1993, 1997 ve 1999 ylllarında pozitif diğer yıllarda negatif değerler almıştır. Ancak bu 10 yıllık periyodun tamamı değerlendirildiğinde enerji tüketiminde 1463 Btep'lik tasarrufa neden olmuştur. Kimya-petrokimya, rafineri, gübre, çimento ve şeker 
endüstrileri enerji tüketimindeki artışa düşürücü etki yaparken, demir-çelik, demir dışı metaller ve diğer sanayi dallarında enerji yoğunluğu artarak enerji tüketimindeki artışa pozitif katkı yapmıştır.

Son olarak 2000-2011 döneminde önceki periyotların aksine enerji tüketimindeki artışa pozitif katkı yapmıştır. Bu dönemde yaratılan reel katma değer \%1 artarken enerji tüketimi \%4 artmış ve dolayısıyla yoğunluk etkisi enerji tüketiminde 7427 Btep'lik artışa yol açmıştır. Şeker, demir dışı metaller ve diğer sanayi dalları haricindeki çimento, kimya-petrokimyarafineri, gübre ve demir-çelik gibi sektörlerde enerji yoğunluğu artarak pozitif değerler almıştır. 2001 ve 2008 yıllarında yaşanan ekonomik krizler dolayısıyla çıktıda yaşanan hızlı düşme nedeniyle söz konusu yıllarda yoğunluk etkisi negatif gerçekleşmiştir.

2000-2011 döneminde yoğunluk etkisinin pozitif çıkmasında şu faktörler etkili olmuştur: 2001 krizinde sanayide yaşanan büyük daralma, küresel piyasalarda yaşanan likidite bolluğunun ham petroldeki fiyat artışlarının etkisini azaltması, enerji tasarrufu ve verimliliğini arttıran teknolojik gelişmelerin ihmal edilmesi, yaratılan reel katma değerde yaşanan yavaşlama ve son olarak 2008 yılının ortalarında başlayan küresel finansal krizle birlikte sanayi sektöründe yaşanan daralma.

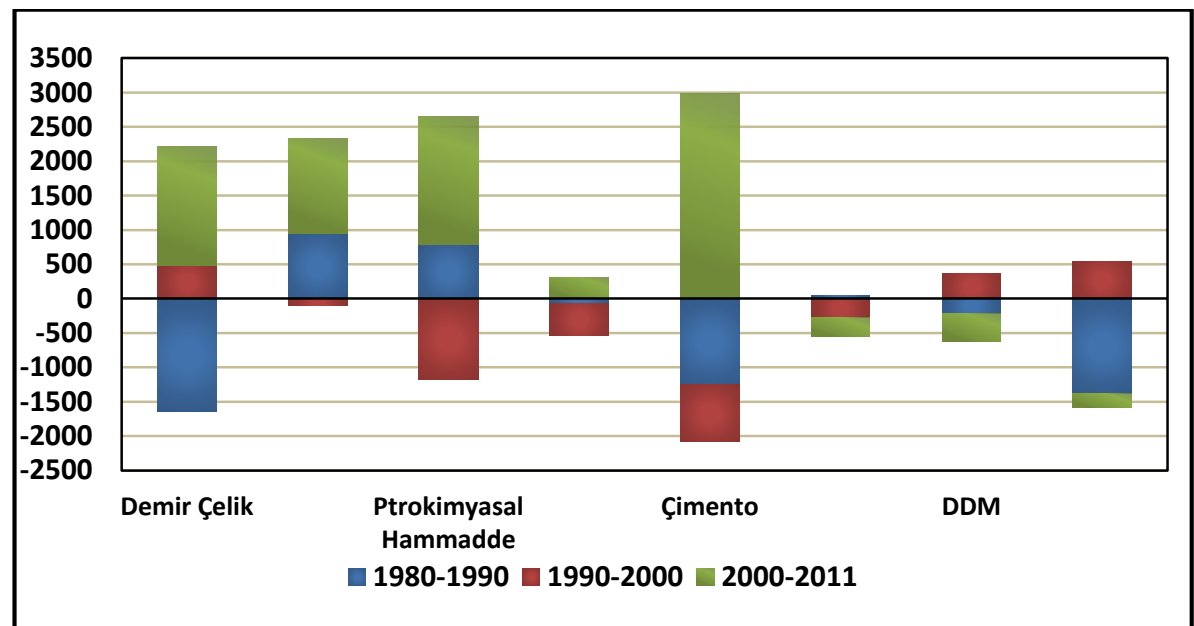

Şekil 7. Yoğunluk Etkisinin Sektörel Ayrımı

Şekil 7'de ise yoğunluk etkisinin sektörel ayrımı verilmiştir. Enerji yoğun sektörler demir çelik, çimento ve petrokimyasal hammadde sektörleridir. Demir çelik sektörü 1980-1990 döneminde tasarruf edici etki yaparken diğer dönemlerde enerji tüketimini arttırıcı etki yapmıştır. Çimento sektörü ise 1980-1990 ve 1990-2000 döneminde enerji tüketimini 
düşürücü etki yaparken 2000-2011 döneminde arttırıcı etki yapmıştır. Petrokimyasal hammadde sektöründe ise 1990-2000 döneminde negatif çıkan yoğunluk etkisi diğer dönemlerde pozitif değerler alarak enerji tüketimini arttırmıştır.

Yapısal etkisinin pozitif veya negatif değerler alması, o sektörün sanayi üretimi içindeki payı ile ilgilidir. Eğer o sektörün sanayi üretimi içindeki payı azalırsa yapısal etkisi negatif, artarsa pozitif değer alacaktır. Bu çalışmada sanayi sektörü 7 alt sektöre ayrılmıştır. Dolayısıyla yapısal etkinin negatif çıkması hem sanayi üretimi içindeki payı düşen sektör sayısına hem de o sektörün ne kadar enerji tükettiğine bağlıdır. Eğer üretim içindeki payı düşen sektör sayısı fazla ve enerji tüketimleri içindeki payı da yüksekse yapısal etki negatif değer alacaktır. Tam tersine eğer üretim içindeki payı artan sektör sayısı ve enerji tüketimi içindeki payı ne kadar fazlaysa yapısal etkisi o kadar artacaktır. Yapısal etkinin pozitif değer alması ilgili yılda toplam sanayi kesimi enerji tüketimi artışı üzerinde arttırıcı etki yaptığını, negatif olması ise düşürücü etki yaptığını gösterir.

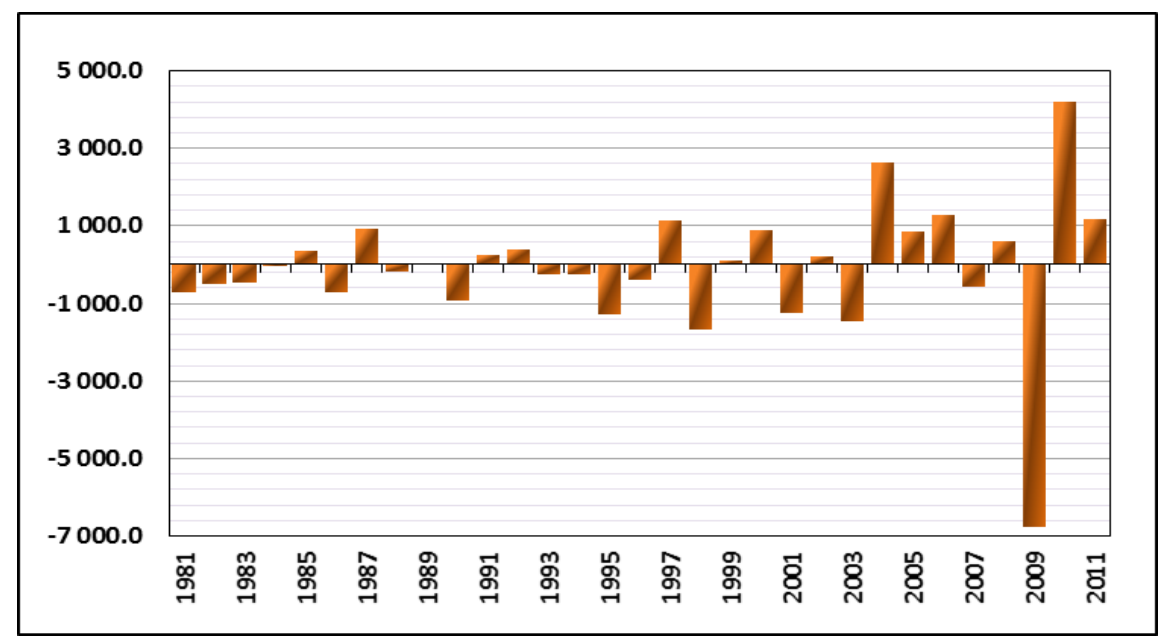

Şekil 8. Yapısal Etki (Btep)

Şekle bakıldığında ilk on yıllık dönemde yapısal etkinin negatif değer aldığı yıllar (1981, 1982, 1983, 1984, 1986 ve 1988), pozitif değer aldığı yıllara göre (1985, 1987 ve 1989) fazladır. Bu periyotta yapısal etki aldığ 1231 Btep değeri ile sanayi sektörü enerji tüketim artışı üzerinde düşürücü etki yapmıştır. Bu dönemde gübre, demir çelik ve demir dışı metaller sanayinin toplam içindeki payının artmasına bağlı olarak yapısal etkisi pozitif, şeker, kimya-petrokimya, petrokimyasal hammadde ve diğer sanayi 
sektörlerinin toplam reel katma değer içindeki payı azalması nedeniyle yapısal etkisi negatif çıkmıştır.

İkinci on yıllık periyotta ise negatif değer alınan yılların sayısı (1990, 1993, 1994 1995, 1996 ve 1998) pozitif değer alınan yılların (1991, 1992, 1997 ve 1999) sayısından fazladır. Mutlak değer olarak da negatif değerler büyük olduğu için ikinci on yıllık dönemde 2915 Btep'lik düşürücü etki yapmıştır. $\mathrm{Bu}$ periyotta demir çelik, kimya petrokimya, gübre, şeker ve demir dışı metaller sanayileri negatif etki yaratırken, petrokimyasal hammadde ve diğer sanayi dalları üretim içindeki paylarını arttırarak yapısal etkilerini pozitife dönüştürmüş ve toplam sanayi enerji tüketimini arttırıcı etki göstermişlerdir.

Son periyotta ise pozitif değer alan yıllarda $(2000,2002,2004,2005$, 2006, 2008, 2010 ve 2011) yapısal etki negatif değer alınan yıllardan (2001, 2003, 2007 ve 2009) mutlak değer olarak daha fazla olduğu için yapısal etki sanayi sektörü enerji tüketiminde 1838 Btep'lik artırıcı etki yapmıştır. Alt sektörler itibariyle kimya, petrokimya, petrokimyasal hammadde ve çimento sektörleri nedeniyle yapısal etki negatif değerler alırken, şeker, demir çelik, gübre, demir dışı metaller ve diğer sanayi dalları toplam katma değer içinde paylarını arttırarak pozitif değerler almışlardır.

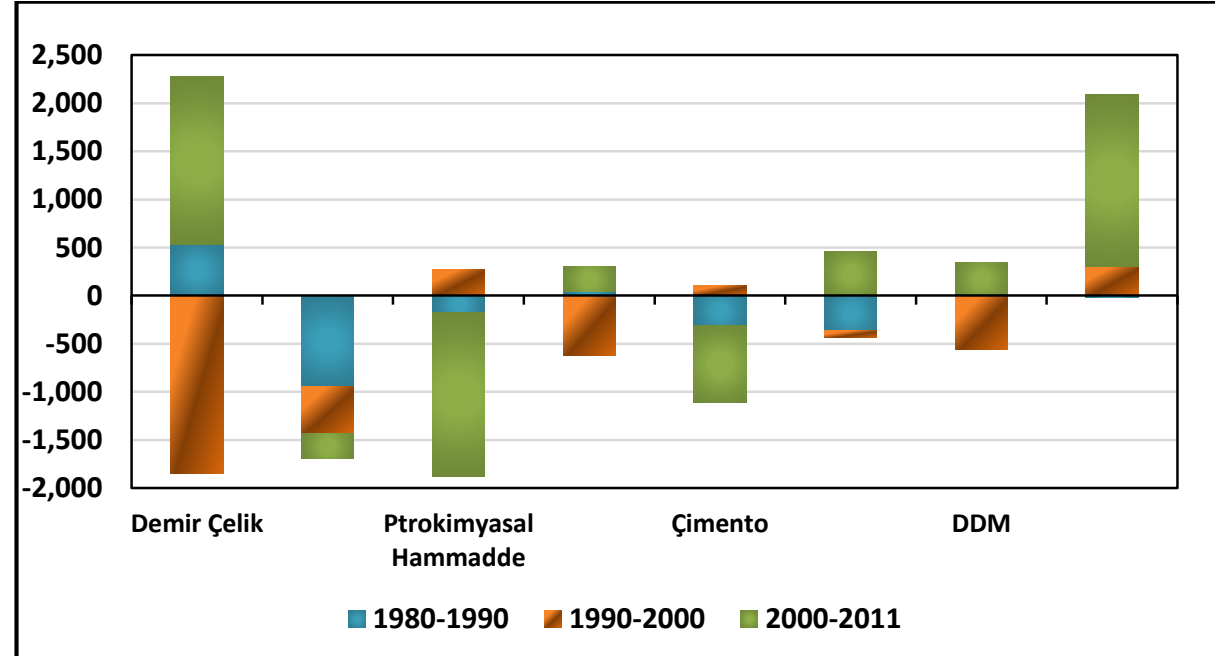

Şekil 9. Yapısal Etkinin Sektörel Ayrımı

Şekil 9'da ise yapısal etkinin sektörlere öre dağılımı verilmiştir. Yapısal etkide öne çıkan sektörler demir-çelik, kimya-petrokimya ve rafineri sektörlerdir. Demir çelik sektörü 1990-2000 harici dönemlerde üretim içindeki payının düşmesi sonucu yapısal etkisini negatife döndürmüştür. 
kimya-petrokimya sektörü ise tüm dönemlerde yaratılan katma değer içindeki payının düşmesi sonucu enerji tüketimindeki artışa düşürücü etki yapmıştır. Rafineri sektörü ise 1990-2000 haricindeki dönemlerde üretimdeki payını azaltarak yapısal etkisini pozitif olarak gerçekleştirmiştir.

\section{Sonuç}

Türkiye ekonomisinde enerji tüketimi 1980 dışa açılma dönemi ile önemli değişikliklere uğramıştır. İthal ikameci dönemde uzun yıllar düşük seyreden petrol fiyatları, ekonomideki devlet desteği, nitelikli işgücü kıtlı̆̆ı ve sendikal hareketlere bağlı olarak yükselen emek fiyatlarının yerine göreli ucuz olan enerjinin ikame edilmesi gibi nedenlerle üretimde enerji bağımlılı̆̆ Böylece verimsiz bir enerji ekonomisi oluşturulmuş, sanayi firmaları enerji verimliliği konusunda gerekli seviyeyi yakalayamamışlardır. Ancak 1980 sonrası ihracata dayalı kalkınma dönemi ile birlikte ekonominin dış rekabete açılması, kapasite kullanımının artması, ar-ge harcamalarının artması, teknolojik gelişmelerin daha yakından takip edilmeye başlanması, ekonomide katma değeri yüksek daha az enerji yoğun sektörlerin payının artmaya başlaması ve petrol krizi ile birlikte enerji fiyatlarının artmasıyla enerji yoğunluğunun düşmeye başladığı, enerji verimliliğinin arttığı yeni bir döneme girilmiştir.

$\mathrm{Bu}$ yeni dönemde enerji sektöründeki en büyük problem yurt dişı kaynaklara olan bağımlılık ve fosil tabanlı yakıtların yoğun kullanımıdır. Bu sürdürülemez tüketim yapısı dış ticaret açığını arttırmakta, arz güvenliğini riske sokmakta ve çevresel açıdan sakıncalar yaratmaktadır. Sağlıklı, sağlam temellere dayanan, sürdürülebilir ekonomik büyüme ve kalkınma için enerji arz güvenliği sağlanmalı, enerji mümkün olduğu kadar düşük maliyetle nihai kullanıcılara ve firmalara sunulmalı, yerli enerji kaynaklarının payı arttırılmalı, enerji verimliliği ve enerji koruma politikalarına önem verilmeli ve alternatif (nükleer veya yenilenebilir enerji kaynakları gibi) enerji kaynakları portföye alınmalıdır.

Enerji ekonomik ve sosyal gelişme için en temel şartlardan biridir. $\mathrm{Bu}$ hedefler doğrultusunda ekonomide olması gereken yapısal dönüşüm, milli gelir içindeki enerji yoğun sektörlerin (demir-çelik, çimento, rafineri, petrokimya gibi) payının azalması, daha az enerji yoğun sektörlerin (yazılım, bilişim sektörleri gibi) payının artmasıdır. Bu dönüşümü tüm gelişmiş ülkeler geçirmişlerdir. İstatistiklere bakıldığında gelişmiş ülkelerde hizmetler sektörünün milli gelir içindeki payı \%70-75 iken Türkiye ekonomisinde \%63-64 seviyesindedir. Yani sektörel yapısal dönüşüm süreci 
tamamlanmamıştır, bu yüzden sektörlerin enerji tüketimindeki paylarının değişimi devam etmektedir.

Analiz sonuçlarına bakıldığında, Türkiye ekonomisi ticari olmayan enerji kaynaklarının daha çok kullanıldığı, endüstrileşme alt yapısının yeni kurulmaya başlandığı, dayanıklı tüketim malları açısından tüketimin artığı ilk safhayı geçirmiştir. Ticari enerji kaynaklarının daha fazla kullanıldığı, dayanıklı tüketim mallarının belli bir doygunluğa ulaştı̆̆ı, sanayi sektörünün milli gelir içindeki payının \%25-30 arasında dengeye geldiği ve genel enerji yoğunluğunun düşmeye devam ettiği ikinci safhayı da tamamlamış ve endüstriyel enerji tüketiminin azaldığı, enerji yoğun olmayan ve yüksek katma değerli sektörlerin milli gelir içinde en fazla paya sahip olduğu, tüketicilerin az enerji sarf eden ürünlere yöneldiği ve enerji yoğunluğundaki düşüşün istikrarlı şekilde belli bir trende oturduğu son safhaya geçmektedir. Üçüncü safhada artık enerji tüketimindeki artış oranı, üretimdeki artış oranının daha da gerisine düşecektir. Böylelikle Türkiye ekonomisinin enerji tüketim yapısı daha sağlıklı bir yapıya dönüşebilecektir.

\section{Kaynakça}

Cornillie J., Frankhauser S. (28 May 2004), The Energy Intensity of Transition Countries, Energy Economics 26 (2004), 283-295.

Dpt (2006), Sekizinci Beş Yıllık Kalkınma Planı (2001-2005), 2005 Yılı Programı Destek Çalışmaları, Ekonomik ve Sosyal Sektörlerdeki Gelişmeler, Ankara.

Fay J. A., and GOLOMB D. S., Energy and the Environment. Oxford University Press, 2002.

Foster V., T. Jean Philippe, W. Quentin (2000), Energy Consumption and Income: An inverted $U$ at the houshold level?, World Bank, September 2000. http://info.worldbank.org/etools/docs/voddocs/240 /502gua _invu2.pdf

Granel, F. (2003), A Comperative Analysis of Index Decomposition Methods, Master Thesis, National University of Singapore, Department of Industrial and Systems Engineering, Singapore.

Greening L.A., Willıam B.D., Schipper L., Khrushch M. (1997), Comparison of SixDecomposition Methods: Application to Aggregate Energy

Intensity for Manufacturing in 10 OECD Countries, Energy Economics 19 (1997) 375-390.

Karluk, R (1999), Türkiye Ekonomisi Tarihsel Gelişim Yapısal ve Sosyal Değişim, 6. Baskı, Beta Yayınevi, İstanbul. 
Kraft, J. and Kraft, A. (1978) "On The Relationship Between Energy and GNP", Journal of Energy and Development, Volume 3.

Ma C., Stern D. I. (2008), China's Changing Energy Intensity Trend; A Decomposition Analysis, Energy Economics 30 (2008) 1037-1053, Volume 30.

Narin M., (2006), Farklı İşyeri Büyüklüğündeki İmalat Sanayi Alt Sektörlerinde Enerji Yoğunluğu, Ekonomik Yaklaşım, Cilt: 17, Sayı: 58, Yıl: 2006. ss-59-87.

Orhan, M. (2007), Enerji Talebinin Kısa ve Uzun Dönem Dinamik Analizi; Türkiye Uygulaması, Erciyes Üniversitesi Sosyal Bilimler Enstitüsü Yüksek Lisans Tezi, Ekim 2007, Kayseri.

Saatçioğlu Cem, Küçükaksoy İsmail ,(2004), Türkiye Ekonomisinin Enerji Yoğunluğu Ve Önemli Enerji Taşıma Projelerinin Ekonomiye Etkisi, Dumlupınar Üniversitesi Sosyal Bilimler Dergisi, Sayı: 11, 19-39.

Steenhof, P. A. (2006), Decomposition of Electricity Demand in China's Industrial Sector, Science Direct Energy Economics, Energy Economics, Volume 28.

Tandoğan A. (1984), Dünya Enerji Üretimi ve Türkiye'nin Enerji Sorunu, Karadeniz Teknik Üniversitesi, İkt. ve İd. Bil. Fakültesi Dergisi, Cilt 1, Sayı 1, Trabzon.

TDK, (1994), Enerji Nedir, Türk Dil Kurumu Yayınları No:603, Ankara.

Vehmas, J. (06.05.2010), AB ve Türkiye'de Enerji ve CO2 Etkinliği Gelişimi, Finlandiya Geleceği Araştırma Merkezi Turku Ekonomi ve İş İdaresi Okulu, $\quad$ http://www.upav.org.tr/project/tr/ teblig/190903_fin_konf.doc.

Zhang, Z. X. (2003), Why Did the Energy Intensity fall in China's Industrial Sector inthe 1990s? The relative Importance of Structural Change and Intensity Change, Science Direct Energy Economics, Energy Economics Volume 25. 